\title{
Measures of Audit Committee Effectiveness in Nigeria
}

\author{
Vera Ekundayo Ph.D \\ Senior Lecturer, Department of Private and Commercial Law, School of Law and Security Studies, Babcock \\ University, Ilishan-Remo, Ogun. \\ Adeyinka Ilori Ph.D \\ Visiting Lecturer Babcock University, Illisan-Remo Ogun State- Nigeria and Leads University, Ibadan- \\ Nigeria..
}

\begin{abstract}
There has been increased focus on the activities of audit committees due to high-profile cases of financial scandals unsettling business executives and organizations. A reliable audit report facilitated by an effective audit committee is now imperative in corporate organizations. Empirical and statistical evidence supports committee tenure, financial expertise, and independence as having significant direct correlation with audit committee effectiveness. However there is no statistical evidence proving that committee size and the frequency of committee meetings impact positively on audit committee effectiveness, as these are discretional, charter-based determinants. Therefore, to forestall the occurrence of anomalies in financial disclosures and to protect corporate reputation and diverse interests of various stakeholders, audit committees must be seen to have the power to probe, forensically and otherwise, management programs and other financial projects. In addition the audit committee has the corporate governance role to monitor, in stricter details, the activities of both Internal and External Audit to prevent biased and scandalous disclosures. The foregoing role of the committee is of utmost importance, as the credibility of financial statements remains the most accurate way of informing shareholders and other stakeholders about the financial performance, progress and position of the company.
\end{abstract}

Keywords: Audit Committee, External Auditors, Governance, Financial Disclosures.

DOI: $10.7176 / \mathrm{RJFA} / 10-10-13$

Publication date:May $31^{\text {st }} 2019$

\section{INTRODUCTION}

All over the world there has been cases of corporate financial scandals and abuse of power by top executives of organizations, leading to losses for investors. ${ }^{1}$ As a result there have been increased demand for the establishment of effective audit committees. ${ }^{2}$ The audit committee's role is one of oversight and monitoring, and in carrying out this responsibility, the committee may rely on management, the External Auditors, and any advisers the committee might engage, provided its reliance is reasonable. ${ }^{3}$ The audit committee is one of the operating committees of the board of directors of organizations saddled with the board responsibility for financial reporting and disclosures. ${ }^{4}$ Membership, compensation and tenure of the committee is dependent on the charter of the company in question. The committee has the responsibility to oversee the firm's financial, accounting reporting processes and preparation of the financial statement in compliance with regulatory standards and relevance statutes. ${ }^{5}$ Non executive Directors are usually inclusive in the membership of the audit committee, however where no audit committee exists in the establishment, the entire board of directors assumes audit committee responsibility.

\footnotetext{
1 See Robert Wearing, Cases in Corporate Governance, Sage Publications (London, Published by SAGE Publications Ltd., 2005) ISBN 10: $1412908760 /$ ISBN 13:9781412908764 .54. EBook available at $<$ www.abebooks.com/Cases-Corporate-Governance-RobertWearing $>$ accessed 8 January 2015. The chairman of BCCI at the time was Clark Clifford, the former US Defense Secretary; The Bank was involved in massive money laundry and financial crime. For more details see $<$ http://www. bibiliotecapleyades.net/socio-political/sociopolglobal banking >accessed February 2015. Poly Peck International (PPI) was a British Textile company, which under the leadership of Asil Nadir experienced unprecedented growth through acquisition and diversification. In 1982 it acquired 57\% shares of Cornell, in 1983 purchased $71 \%$ stake in Santana Inc., in 1986 and 1987 it acquired majority shares in Impact textiles and Palm (UAE) respectively. In 1984 it diversified into electronics and acquired 82\% ownership of Turkey electronics and in $198951 \%$ in Sanusi a Japanese electronics company. The CEO of Polly Peck International Asil Nadir was later convicted in 2012 for stealing over 29 million dollars from the company<www.dailymail.co.uk/jailed poly-peck-fraudsters $>$ accessed 9 September 2014. Enron corporate governance scandal was the most notorious. It brought into prominence the importance of good corporate governance. Enron was an American energy company; it was one of the 10 largest companies in the US with over 22,000 staff strength. The company's sudden collapse took the world by storm as it filed for bankruptcy in December 2001.Its sudden collapse was attributed to failures in corporate governance. For instance the executives permitted misleading treatment of transaction in company's account, the Audit Committee gave approval of misleading sets of account and board was ineffective in supervising actions of senior executive and ignored warnings from whistleblowers.

${ }^{2}$ Pandit, G.M., Conway, G.M., and Baker, C.R. (2017). Audit Committee Requirements in Six Major Makets: How Far Have We Come? International Journal of Disclosure and Governance, February, Vol. 14, Iss. 1, pp. 30-61.

${ }^{3}$ The Role of Audit Committee. April 2018. https://www2.deloitte.com/content/dam/Deloitte/us/Documents/center-for-board-effectiveness/usaudit-committee-resource-guide-section-2.pdf

${ }^{4}$ Nigerian Code of Corporate Governance 2018, principle 11. Central Bank of Nigeria Code of Corporate Governance for Banks and Discount Houses in Nigeria 2014, section 2.5.1

${ }^{5}$ Verschoor, C.C. (2008). Audit Committee Essentials. USA: John Wiley \& Sons.
} 
Consequently, the effectiveness of audit committee have a rippling effect on board performance.

Time is fast changing where board performance is evident mainly on choice of Chief Executives and protection of shareholders' diverse interests. A core challenge is the integrity of the financial reports generated based on the internal and external audit processes. According to Copnell, greater pressure is placed on audit committees due to changes in corporate cultures, shortage of key talents in the finance function, the new global control environment, and changes in legal and regulatory compliance environments. ${ }^{1}$ The study by KPMG concluded that risk management is a serious concern to audit committees. ${ }^{2}$ Other concerns include the tone at the top, short-termism, Chief Financial Officer's (CFO) succession planning and competence in the finance function, and poor understanding of the firm's business. ${ }^{3}$ In spite of frequent development in technology such as computer assisted audit technique, internet, automated accounting system etc, financial scandals in both public and private organizations still top the headlines of Nigerian newspapers on daily basis. ${ }^{4}$

Business operations are required to be reported using internal and external financial reporting standards given by regulators. More so information disclosed by organizations form part of the requirements for investments, lending, regulation, and policymaking. ${ }^{5}$ However in the absence of a well-regulated financial reporting environment, the outcome of a firm's financial position may be under-reported, giving exaggerated assumptions of firm value and efficiency, with severe consequences to the user of the information. ${ }^{6}$ Regulators and investors do not only care about the information produced but also how the information is made available and the audit committee plays a vital role in this regard. The form of the information can be deceptive, especially if a financial statement bears a footnote projected as earnings of the company rather than additional information to justify the earnings. In an under-regulated environment, it is not impossible to see disparate financial information content and variances in the ways financial information is disclosed. ${ }^{7}$ Studies show that organizations doing the right things disclose quality information faster than firms fabricating financial reports ${ }^{8}$ and using more than necessary external auditors and analysts ${ }^{9}$ whose activities are marred by a lack of objectivity, partiality, and corporate connivance in information disclosure scandals. ${ }^{10}$ Fraudulent organizations have been observed to exhibit enormous inconsistencies between revenue growth reported and growth in revenue-related non-financial metrics such as number of employees, stores, and patents. ${ }^{11}$

The purpose of this paper is to review key literature to espouse the perceptions of the effectiveness of audit committees from the practice-theory perspective. ${ }^{12}$ The study design involves collecting secondary data available in the public domain to evaluate the effectiveness of audit committees. First, the study reviews the practice of audit committees within their role as members of boards of directors. Next, a review of literature is undertaken to bring into perspective the descriptions and behavior of audit committees in their independent function of monitoring financial reporting and strengthening corporate governance. ${ }^{13}$ The paper examines audit committees' best practices against what they actually do. It measures the relationship between what they do and what is expected of them within the framework of their roles and expectations from key stakeholders. In addition, this paper scrutinizes the legal framework of the audit committee as provided by relevant laws and codes of governance in Nigeria. Some of such laws and codes includes The Company and Allied matters Act (CAMA) 2011, Security and Exchange Commission Code of Corporate Governance for Public Companies (SEC Code 2011) 2011, the Financial Reporting Council of Nigeria Act 2011 and the most recent Codes which are the Nigerian National Code of Corporate Governance 2018 (NCCG) and the Code of Conduct for Microfinance Banks 2018.

\footnotetext{
Copnell, T. (2016).Four Key Challenges for Global Audit Committees. UK: Audit Committee Institute, KPMG LLP. https://home.kpmg.com/content/dam/kpmg/pdf/2016/04/Four\%20Key\%20Challenges.pdf. Accessed on May 14, 2018.

$2 \mathrm{https} / /$ home.kpmg/us/en/home/media/press-releases/2017/01/risk-management-tops-audit-committee-concerns.html

${ }^{3}$ Partiban, J., Gajula, R., and Cardwell, F. (2017). Is Everything Under Control? Audit Committee Challenges and Priorities. 2017 Global Audit Committee Pulse Survey. KMPG's Audit Committee Institute. Bahrain: KMPG Fakhra. https://home.kpmg.com/content/dam/kpmg/bh/pdf/2017-global-audit-committee-pulse-survey.pdf. Accessed on May 14, 2018.

${ }^{4}$ Thisday Newspaper, 16th Oct., 2006 and Sunday Punch June 26, 2011, page 1

${ }^{5}$ Gunn, J. (2007). XBRL: Opportunities and Challenges in Enhancing Financial Reporting and Assurance Processes. Current Issues in Auditing, Vol. 1, pp. A36-A43.

${ }^{6}$ Guay, W. and Verrecchia, R. (2018).Conservative Disclosure.Financial Reporting.In Press. DOI: https://doi.org/10.2308/jfir-52051.

${ }^{7}$ Hirshleifer, D. and Teoh, S.H. (2003).Limited Attention, Information Disclosure, and Financial Reporting.Journal of Accounting and Economics, Vol. 36, pp. 337-386.

${ }^{8}$ Abernathy, J.L., Kubick, T.R., and Masli, A. (2018).Evidence on the Relation between Managerial Ability and Financial Reporting Timeliness.International Journal of Auditing, February 19. DOI: https://doi.org/10.1111/ijau.12112.

${ }^{9}$ Young, A. (2018). Do Analysts affect Bad News Timeliness? Accounting and Business Research, Vol. 48, Iss. 2, pp. $171-189$.

${ }^{10}$ Clatworthy, M. and Lee, E. (2018).Financial Analysts' Role in Valuation and Stewardship.Accounting and Business Research, Vol. 48, No. 1, pp. 1-4.

${ }^{11}$ Brazel, J.F. and Schmidt, J.J. (2018). Do Auditors and Audit Committees Lower Fraud Risk by Constraining Inconsistencies between Financial and Non-Financial Measures? Auditing: A Journal of Practice and Theory.In Press. https://doi.org/10.2308/ajpt-52087.

${ }^{12}$ Brennan, N. and Kirwan, C.E. (2015). Audit Committees: Practices, Practitioners and Praxis of Governance. Accounting, Auditing, and Accountability Journal, January, Vol. 28, Iss. 4, pp. 466-493.

${ }^{13}$ Beasley, M.S., Carcello, J.V., Hermanson, D.R., and Neal, T.L. (2010).The Audit Committee Oversight Process. Contemporary Accounting Research, Spring, Vol. 26, Iss. 1, pp. 65-122.
} 


\section{THE BOARD OF DIRECTORS}

The Board, being central in corporate governance and one of highest governing body in the company, is expected to have a charter setting out its responsibilities. ${ }^{1}$ Boards of directors are key formations of the governance architecture of organizations. A Board ( specifically in Nigeria) is expected to have a Chairman, the position which should be distinct and separate from that of the Managing Director/Chief Executive Officer, hence no two persons should combine the two offices. ${ }^{2}$ Furthermore neither the Chairman nor the MD/CEO should serve as chairman of any of the Board committees including the audit committee. ${ }^{3}$ The Board owes the company fiduciary duties and duties of care and skill, it is in carrying out these duties towards the company that their roles as board audit committee arise.

Advances in economic theory propose that board of directors is saddled with the responsibility to secure enduring performance for the entity. ${ }^{4}$ The size of the board is immaterial to the value expected from the members. ${ }^{5}$ Therefore; board effectiveness is a function of the individual members of the body. Prior research brought evidence of the influence of board composition for bringing strategic resources for innovation, as well as evidence of positive outcomes of board diversity. ${ }^{6}$

Being appointed as a director to the board of a company is a mark of a top management career. A company director is a person duly appointed by the company to direct and manage the business of the company. ${ }^{7}$ A director is the alter ego of a company, a corporate governor in charge of the affairs of a company. Directors of a company registered under the CAMA are persons duly appointed by the company to direct and manage the business of the company. CAMA describes a director to include any person occupying the position of director by whatever name called; and includes any person in accordance with whose directions or instructions the directors of the company are accustomed to act. $^{8}$

\section{BOARD AND AUDIT COMMITTEE}

Directors are engaged in various committees, such as audit, nominating, compensation, and executive committees, as they perform the responsibilities of their offices. Directors are sourced internally and externally based on competencies and experience possessed. Directors sourced internally typically are current or former employees of the firm. These have impressive knowledge of the organization and have generously risen through the ranks, serving in various capacities in the firm. Usually, directors are enticed with equity ownership, performance-based fees and other emoluments to improve their welfare, status, and focus on driving company performance. ${ }^{9}$ The Chief Executive Officer exerts relative influence over the board of directors. This relativity results from factors such as board size, number of non-executive directors, number of Independent directors, the number of board meetings, the existence of all executive committees etc. ${ }^{10}$

To ensure effectiveness in the running of the company, the board has been empowered by numerous codes of corporate governance in Nigeria to establish board committees. A good example of such code is the National Code of Corporate Governance (NCCG) 2018 which empowers the board to delegate its powers and duties to properly structured sub-committees usually known as board committees. ${ }^{11}$ These committees may include remuneration committee, risk management committee, audit committee, nomination and governance committee. ${ }^{12}$ Only directors are required to be members of board committees, although members of senior management may be required to attend board committee meetings, provide support and advisory role and carry out certain task to facilitate the attainment of committee responsibilities. ${ }^{13}$ Board committees are accountable to the board for their activities and performance. The Central Bank of Nigeria (CBN) Code of Corporate Governance for Banks and Discount Houses 2014 also provides for the creation of board committees. In Section. 2.5.5 of the code it provides that the Board should establish at a minimum the following Committees: (i) a committee responsible for the oversight of Risk Management and Audit functions and (ii) a Board Governance and Nominations Committee.

\footnotetext{
1. Nigerian Code of Corporate Governance 2018 Principle 1

${ }^{2}$ Central Bank of Nigeria Code of Corporate Governance 2014, section 2.3. similar provision in the NCCG 2018, section 2.7

${ }^{3}$ Central Bank of Nigeria Code of Corporate Governance 2014, section 2.5.3. similar provision in the NCCG 2018, section 2.9

${ }^{4}$ Baysinger, B.D. and Butler, H.N. (1985). Corporate Governance and the Board of Directors: Performance Effects of Changes in Board Composition. Journal of Law, Economics, and Organisation, Vol. 1, No.1,pp. 101-124.

${ }^{5}$ Yermack, D. (1996). Higher Market Valuation of Companies with a Small Board of Directors.Journal of Financial Economics, February, Vol. 40, Iss. 2, pp. 185-211.

${ }^{6}$ Fabrice Galia and Emmanuel Zenou 'Does board diversity influence innovation? The impact of gender and age diversity on innovation types' Clermont-Ferrand, 10-12, June 2013

${ }^{7}$ Company And Allied Matters Act, section244

8 ibid

${ }^{9}$ Yermack, D. Supra

${ }^{10}$ Lara, J.M.G., Osma, B.G., and Penalva, F. (2007). Board of Directors' Characteristics and Conditional Accounting Conservatism: Spanish Evidence. European Accounting Review, April 08, Vol. 16, Iss. 4, pp. 727-755.

${ }^{11}$ Nigerian Code of Corporate Governance, 2018 Principle 11, 2018.

12 ibid

${ }^{13}$ Nigerian Code of Corporate Governance, 2018.principle 11.1.2
} 
The Nigerian Security and Exchange Commission (SEC) Code 2011 for Public Companies in addition to the statutory audit committee required by the CAMA, provides that every public company through its board may establish an internal audit committee. ${ }^{1}$ The code stipulates that at least one board member of the committee should be financially literate, ${ }^{2}$ however the Nigerian code recommends that all Members of the committee should be basic financially literate and should be able to read financial statements, at least one member should be a financial expert have current knowledge in accounting and financial management. ${ }^{3}$ This goes to show that the composition of the board audit committee affects its effectiveness whether positively or negatively in carrying out its duties. The SEC Code 2011 further mandates companies who refuse to establish an internal audit committee, to disclose sufficient reasons in the company's annual report with an explanation as to how assurance of effective internal processes and systems, such as risk management, internal control will be obtained. ${ }^{4}$

Without prejudice to the extant laws on statutory audit committee, the NCCG 2018 prescribes also that it is desirable for every company to have a board audit committee responsible for the oversight function of audit. ${ }^{5}$ The members of the board should be financially literate and should be able to read and understand financial statement. It also provides that at least one member of the committee should be a financial expert, have current knowledge in accounting and financial management, and be able to interpret financial statements. ${ }^{6}$ The NCCG 2018 Code which is all encompassing, applies to companies of various sizes and types, stipulates that for private companies, members of the board audit committee should be Non-Executive Directors and a majority of them should be Independent Non-Executive Directors where possible. This provision is similar to that of CBN Code 2014 which states that board audit committee should be structured in such a way that it consists only of Non-Executive Directors; chaired by an independent Director; and has at least three members. ${ }^{7}$ This is to aid the process of transparency in the accounting/auditing process of the company. Due to the aforementioned provisions, the audit committee can check the activities of the company and its officers including the executive directors, for errors and fraudulent activities. The presence of independent directors on the audit committee increases trust in the financial information turned out by the committee, this is because independent directors are "independent" of the company and can make decisions without fear or favor.

From existing law and codes, it is now established that there are two categories of audit committees recognized in Nigeria. The first is the statutory audit committee which is compulsory for every company under the CAMA and it is sometimes referred to as the external audit committee. The second category of audit committee is the internal audit committee is also called the board audit committee. The internal or board audit committee which has been recommended by SEC CODE 2011, CBN Code 2014 and more recently the NCCG 2018. The CBN Code 2014 provides that the internal board committee for banks and other financial institutions is to be headed by NonExecutive Directors and must not include the chairman of the board.$^{8}$ It is fast becoming the practice for a Nigerian company especially public companies, to have a two tier audit committee alongside independent auditors, It is believed that this will translate into higher audit quality, improved risk management environment, and higher professional fees to be borne by the firm. ${ }^{9}$ It is important to note as earlier mentioned, that Section 359 of the CAMA only provides for one audit committee which is the statutory audit committee. It prescribes that the committee be made up of an equal number (maximum of six) of representatives of shareholders and directors.

Onyabe et al opine that audit committee tenure has no significant effect on the quality of audit reports and the general effectiveness of the committee. ${ }^{10}$ Drawing a parallel between tenure and audit committee fees, Schrader observed positive direct correlation, suggesting that the effectiveness of the audit committee has a link to the tenure of its members. The foregoing disparity notwithstanding, Ghafran recommend that to achieve a more effective audit committee, the committee should work with management to ensure that a significant negative association that results in delays and lag periods in financial reporting timeliness is eliminated. ${ }^{11}$

In Nigeria today, for a company to be listed on Stock Exchanges, an audit committee is mandatory. ${ }^{12}$ Whilst CAMA permits the chairman of the board audit committee to maintain basic financial and accounting knowledge, ${ }^{13}$

\footnotetext{
${ }^{1}$ Section 9.2

${ }^{2}$ Section 30.1 and 2

${ }^{3}$ NCCG 2018, section 11.4.2

${ }^{4}$ Section 31.1

${ }^{5}$ Section 11.4.1

${ }^{6}$ Nigerian Code of Corporate Governance 2018 Principle 11.4.2

${ }^{7}$ See section 2.5.2, Central Bank of Nigeria Code 2014

${ }^{8}$ Section 2.5.4 CBN Code of Corporate Governance 2014

${ }^{9}$ Rani, A. (2018). Audit Committee Effectiveness: Relationship between Audit Committee Characteristics and Audit Fees and Non-Audit Service Fees. Journal of Commerce and Accounting Research, Vol. 7, Iss.3, pp.35-44.

${ }^{10}$ Onyabe, J.M., Okpanachi, J., Nyor, T., Yahaya, O.A., and Ahmed, M. (2018).Effect of Audit Committee Tenure on Financial Reporting Quality of Listed Deposit Money Banks in Nigeria.European Scientific Journal, February, Vol. 14, No. 4, pp. $257-271$.

${ }^{11}$ Ghafran, C. and Yasmin, S. (2018). Audit Committee Chair and Financial Reporting Timeliness: A Focus on Financial, Experiential and Monitoring Expertise. International Journal of Auditing, March, Vol. 22, Iss. 1, pp. 13-24.

${ }^{12} \mathrm{http}$ //www.nse.com.ng/issuers/listing-your-company/listing-requirements Accessed 29/3/ 2019

${ }^{13}$ See section 359 of CAMA
} 
the Financial Reporting Council of Nigeria maintains that for consistency and reliability of financial statements reported in annual reports and other documents of a financial nature, members of the audit committee must possess membership of a professional accounting body in Nigeria. ${ }^{1}$

This paper however aligns with the view of Krishnan, His view is that appointment of experts onto audit committee is more likely to enhance monitoring. Furthermore that it signals that investors are likely to perceive the firm as credible and serious in its commitment to disclosure of quality information necessary for investments and policymaking. ${ }^{2}$

\section{AUDIT COMMITTEE RESPONSIBILITIES}

The role of audit committees in the monitoring financial reporting of a firm's business is of concern to the public, regulators and investors. ${ }^{3}$ Audit committees are set up to forestall the occurrence of anomalies in corporate governance, thus protecting the reputation of firms and interests of various stakeholder groups. They achieve this by questioning management's financial judgments, probing every project and program to determine the appropriateness of budgets and allocations ${ }^{4}$

Audit committees perform the function of whistle-blowers in their drive to ensure that financial disclosures are made and resolved using internal mechanisms without the probability of reporting internal misconducts externally. ${ }^{5}$ However, there is an overlapping function as audit committees perform the function of enterprise risk management, especially in adequately depicting and reporting financial valuations, estimates and other accounting inputs of businesses. ${ }^{6}$ Other duties include integrated reporting of sustainability information to ensure harmony with other relevant internal data. ${ }^{7}$ It is however important to note that the SEC Code 2011, CBN Code 2014 and Code of Corporate Governance for Micro Finance Banks and other Financial Institutions 2018 have similar provisions on the responsibilities of audit committees. ${ }^{8}$

The NCCG Code 2018 stipulates some of the responsibilities of audit committees thus; ascertaining whether the accounting and reporting policies of the company are in accordance with legal requirements and agreed ethical practices, make recommendations to the board regarding the appointment, removal and remuneration of the external auditors of the company. ${ }^{9}$ Furthermore, the board audit committee shall authorize the internal auditor to carry out investigations into any activities of the company which may be of interest or concern to the committee.

\section{MEASURES OF AUDIT COMMITTEE EFFECTIVENESS}

The board (including the audit committee), management (including the internal audit function), and the external auditor all have distinct roles to play in financial reporting, however, the focus of this paper is on the role of board audit committee. The audit committee has the responsibility to ascertain whether the accounting and reporting policies of the Company are in accordance with legal requirements and agreed ethical practices, review the scope and planning of audit requirements, keep under review the effectiveness of the Company's system of accounting and internal control, make recommendations to the Board regarding the appointment, removal and remuneration of the external auditors of the Company, exercise oversight over management's processes to ascertain the integrity of the Company's financial statements, ensure company's compliance with all applicable legal and other regulatory requirements for financial reporting and disclosures. In addition, the audit committee also review performance and exercise oversight function of the Company's internal audit and external auditor's functions, ensure the development of a comprehensive internal control framework for the Company, review and ensure that adequate whistle-blowing policies and procedures are in place. Audit committee is also responsible for developing policy on the nature, extent and terms under which the external auditors may perform non-audit services and review the independence of the external auditors in line with corporate governance best practices.

According to DeZoort et al, the effectiveness of audit committees hinges on the qualification of its members

\footnotetext{
${ }^{1}$ See section 359 (3) and (6) of CAMA Cap. C20. See also Egwuatu, P. (2017). What CAMA Says on Audit Committee Membership. Vanguard, February 20. Available at: https://www.vanguardngr.com/2017/02/cama-says-audit-committee-membership/. Accessed on April 30, 2018.

${ }^{2}$ Krishnan, G.V. and Visvanathan, G. (2008). Does the SOX Definition of an Accounting Expert Matter? The Association between Audit Committee Directors' Accounting Expertise and Accounting Conservatism.Constemporary Accounting Research, Fall, Vol. 25, No. 3, pp. 827857.

${ }^{3}$ Kalelkar, R., Khan, S., and Park, S.J. (2018). Excess Audit Committee Compensation and Audit Pricing.International Journal of Accounting, Auditing and Performance Evaluation, Vol. 14, Iss.2-3, pp. 159-182, https://doi.org/10.1504/IJAAPE.2018.091062.

${ }^{4}$ McMullen, D.A. and Raghunandan, K. (1996).Enhancing Audit Committee Effectiveness.Journal of Accountancy, August, Vol. 182, Iss. 2, pp. 79-81.

${ }^{5}$ Lee, G. and Fargher, N.L. (2018).The Role of the Audit Committee in their Oversight of Whistle-Blowing.AUDITING: A Journal of Practice and Theory, February, Vol. 37, No. 1, pp. 167-189.

${ }^{6}$ Cohen, J., Krishnamoorthy, G., and Wright, A. (2017). Enterprise Risk Management and the Financial Reporting Process: The Experiences of Audit Committee Members, CFOs and External Auditors. Contemporary Accounting Research, Summer, Vol. 34, Iss. 2, pp. 1178-1209.

${ }^{7}$ Chariri, A. and Januarti, I. (2017). Audit Committee Characteristics and Integrated Reporting: Empirical Study of Companies Listed on the Johannesburg Stock Exchange. European Research Studies Journal, Vol. 20, Iss. 4B, pp. 305-318.

${ }^{8}$ See Sections 2.5 CBN Code, Section 30 Code of corporate Governance for Public Companies,

${ }^{9}$ Principle 11. NCCG 2018
} 
and the authority and resources provided by the commissioning firm to carry out their broad functions that secures stakeholders' interests through diligent oversight function. ${ }^{1}$ In addressing audit committee effectiveness, the authors' model highlights the key inputs that facilitate audit committee effectiveness process, and the expected output. The key determinants of audit committee effectiveness include the committee's composition (expertise, independence, tenure, etc.), authority (roles and influence), and resources (e.g., access to management, external and internal auditors). The three broad inputs require diligence on the part of the committee for effectiveness. Turley and Zaman found that the informal networks formed by audit committee members are preconditions of the committee's success and that the success of the job process of the committee lies on the firm's formal governance structures and accounting processes. ${ }^{2}$

Audit committee tenure has become the focus of several debates. The resulting dilemma is that the firm is faced with the decision of whether to replace its audit committee members after a short period of time or to build and maintain a long-term tenure. The outcomes are quite conflicting. While some researchers have identified negative relationship between audit committee tenure and financial reporting quality ${ }^{3}$ others argue on positive relationship between audit committee tenure and financial reporting quality. ${ }^{4}$ Prolonged tenure ordinarily leads to familiarity between the audit committee members and the external auditors and also between the audit committee members and those responsible for the internal audit in the company. Where too much familiarity exist, it is likely to erode objectivity and create bias on the audit committee review of internal audit and external audit function.

The study by Alqatamin focused on companies listed on Amman Stock Exchange. It found that audit committee performance is a function of the committee size, its independence, and gender diversity. ${ }^{5}$ As the hope of all investors and corporate accountability, audit committees are smaller in size compared to the size of the board of directors. The Security and Exchange(SEC) of the U.S., in 1999, proposed a 3-man audit committee comprised of independent directors who exert no influence over management and the firm and vice versa. In 2002, the Sarbanes-Oxley Act of the United States upheld and legislated the proposed SEC audit committee size into Law in Section 301 of the Act. ${ }^{6}$

In studying the effectiveness of audit committees, Alqatamin compared audit committee characteristics with return on asset (ROA), return on equity (ROE), and net interest margin (NIM) of Turkish and United Kingdom banks. The following audit committee characteristics were evaluated - audit committee size, members independence, frequency of meetings, financial expertise, level of education, age, experience, and gender. The study found that the issue of frequency of meeting is usually discretionary and is determined by the levels of ownership of the firm, the size of the committee, its level of independence and financial expertise, especially when the risk of disclosing bad financial information is apparent. ${ }^{7}$ Another study on audit committee effectiveness of quoted Pharmaceutical companies in Nigeria shows improvement in financial reporting timeliness ${ }^{8}$ whereas the effectiveness of audit committees does not translate to improvement in the value of deposit money banks in the country. ${ }^{9}$ Also statistically insignificant is the number of meetings of the committee when measured against the quality of financial reporting of listed Nigerian Banks on the Nigerian Stock Exchange. ${ }^{10}$

The study by Modum, Ugwoke, and Onyeanu observed that the quality of audit committee composition supports improved corporate governance rather than just having a committee in place. ${ }^{11}$ The study found that more than $80 \%$ of audit committees in Nigeria's non-financial sector are weakly constituted with majority of the members lacking expertise in finance and financial reporting standards and insufficient knowledge of their organizations.

\footnotetext{
1 "Audit Committee Effectiveness: A Synthesis of the Empirical Audit Committee Literature. https://digitalcommons.kennesaw.edu/facpubs/1495/

2 Turley, S. and Zaman, M. Supra

${ }^{3}$ Madawaki, Abdulkadir \& Amran, Noor. (2013). Audit Committees: How They Affect Financial Reporting in Nigerian Companies. Journal of Modern Accounting and Auditing. 9. 1070-1080.

${ }^{4}$ Joseph Majiyebo Onyabe, Joshua Okpanachi, PhD Terzungwe Nyor, PhD Onipe Adabenege Yahaya, PhD 'Effect of Audit Committee Tenure on Financial Reporting Quality of Listed Deposit Money Banks in Nigeria' European Scientific Journal February 2018 edition Vol.14, No.4 ISSN: 1857 - 7881 (Print) e - ISSN 1857- 7431

${ }^{5}$ Alqatamin, R.M. (2018). Audit Committee Effectiveness and Company Performance: Evidence from Jordan. Accounting and Financial Research, Vol. 7, No. 2, pp. 48-60.

${ }^{6}$ Kim, S. and Klein, A. (2017). Did the 1999 NYSE and NASDAQ Listing Standard Changes on Audit Committee Composition Benefit Investors? The Accounting Review, November, Vol. 92, No. 6, pp. 187-212.

${ }^{7}$ Sharma, V., Naiker, V., and Lee, B. (2009). Determinants of Audit Committee Meeting Frequency: Evidence from a Voluntary Governance System. Accounting Horizons, September, Vol. 23, No. 3, pp. 245-263.

${ }^{8}$ Ozoanigbo, C.V., Orjinta, I.O., and Ofor, T.N. (2016). Audit Committee Effectiveness and Timeliness of the Financial Reporting In Nigeria. Approaches in International Journal of Research Development, Vol. 10, No. 1, pp. 26-39.

${ }^{9}$ Dauda, I.A. (2015). Effectiveness of Audit Committee Practices and the Value of Listed Deposit Money Banks in Nigeria.European Journal of Accounting, Auditing, and Finance Research, June, Vol. 3, No. 6, pp. 80-90.

${ }^{10}$ Moses, T. (2016). Audit Committee Number of Meetings and Earnings Management in Quoted Nigerian Banks. International Journal of Advanced Academic Research, Social and Management Sciences, June, Vol. 2, Iss. 6, pp. 14-23.

${ }^{11}$ Modum, U., Ugwoke, R.O., and Onyeanu, E.O. (2013). Audit Committees and Corporate Performance of Selected Companies Quoted in the Nigerian Stock Exchange: A Perception Analysis. Research Journal of Finance and Accounting, Vol. 4, No. 16, pp. 115-124.
} 
The effectiveness of financial reports is measured against financial reporting standards, whilst audit committee characteristics, its compliance to standards of reporting, financial literacy, and independence highlight the committee's effectiveness in promoting corporate integrity. ${ }^{1}$ The avoidance of biased metrics in accrual measurements provides insights into how audit committees control firm earnings and tracks erroneous earnings from being entered into financial statements. ${ }^{2}$ Financial expertise and relative status of the committee have also been promoted as the ideal for audit committee effectiveness, especially when faced with conflicting goals and drive to influence outcomes. The quest to deepen accrual, personnel and external auditor monitoring quality has led to improvement in audit committee compensation which has introduced effectiveness in corporate governance. ${ }^{3}$ However, to enhance monitoring and risk avoidance on key audit matters, there is increased call for improvement in the percentage of women on audit committees. ${ }^{4}$ There is also a call to focus on external auditors to prevent the delivery of a poorly reported financial outlook. ${ }^{5}$

Besides the traditional approaches above, audit committee diligence has been measured against the frequency of meetings held. ${ }^{6}$ The committee size has been observed to exert measurable influence on the quality of audits. ${ }^{7}$ Besides the committee size, the authors also provided insight into CEO/Chair's dual roles on the Board and audit committee as a measure of the committee's effectiveness. A key determinant of audit committee members' role effectiveness is their behavior and approach toward evolving quality audit. Members' behaviors is measured against transparency and collaborative tendencies ${ }^{8}$ which contribute to audit committee's diligence just the way the committee's tenure and earnings quality have been explored as a measure of its effectiveness in delivering quality financial audits. ${ }^{9}$ The study by Lawrence et al found that independence and ctivity level of the committee impacts on its effectiveness. ${ }^{10}$ While using units of measurement is sufficiently cumbersome in understudying audit committee characteristics and effectiveness, using a combination of measurement parameters explores greater corporate governance mechanisms in more detail, thus exposing, effectively, the impact of audit committees on the demand for audit quality. ${ }^{11}$

\section{CONCLUSION AND RECOMMENDATIONS}

The objective of financial reporting is to provide high quality financial information about economic entities that can be useful when making economic decisions. Audit committees play very important roles in organizations to secure their integrity and position them for improved investor confidence. Members of the audit committee must be questioned whether they carried out their duties and obligations with due care and diligence. Notwithstanding the independence which the audit committee is meant to possess, they are answerable to the board and the shareholders of the company hence they must be checked to ensure that their duties and responsibilities towards the company are not lacking. Advanced audit skills are required of professionals to cope with the fast changing world of globalization and advancement in information technology ${ }^{12}$. Without the committees focus, many firms have been marred by corporate scandals involving boards of directors manipulation of financial statements for selfish interests. The need for increased monitoring and appointment of financial experts have been thought of and promulgated as laws in many countries as prerequisites for being listed on stock exchanges. However, there is

${ }^{1}$ Song, J. and Windram, B. (2004).Benchmarking Audit Committee Effectiveness in Financial Reporting International Journal of Auditing, November, Vol. 8, Iss. 3, pp. 195-205.

${ }^{2}$ Klein, A. (2002). Audit Committee, Board of Director Characteristics, and Earnings Management. Journal of Accounting and Economics, August, Vol. 33, Iss. 3, pp. 375-400.

${ }^{3}$ Engel, E., Hayes, R.M., and Wang, X. (2010). Audit Committee Compensation and the Demand for Monitoring of the Financial Reporting Process. Journal of Accounting and Economics, February, Vol. 49, Iss. 1-2, pp. 136-154.

${ }^{4}$ Velte, P. (2018). Does Geeder Diversity in the Audit Committee Influence Key Audit Matters Readability in the Audit Report? UK Evidence.Corporate Social Responsibility and Environmental Management, March 23, https://doi.org/10.1002/csr.1491. See also Aldamen, H. and Hollindale, J. (2018).Female Audit Committee Members and their Influence on Audit Fees.Accounting and Finance, March, Vol. 58, Iss. 1, pp. 57-89.

Zalata, A.M., Tauringana, V., and Tingbani, I. (2018). Audit Committee Financial Expertise, Gender, and Earnings Management: Does Gender of the Financial Expert Matter? International Review of Financial Analysis, January, Vol. 55, pp. 170-183, https://doi.org/10.1016/j.irfa.2017.11.002

${ }^{5}$ Chen, S. and Komal, B. (2018). Audit Committee Financial Expertise and Earnings Quality: A Meta-Analysis. Journal of Business Research, March, Vol. 84, pp. 253-270, https://doi.org/10.1016/j.jbusres.2017.11.048.

${ }^{6} \mathrm{Wu}$, J., Habib, A., Weil, S., and Wild, S. (2018). Exploring the Identity of Audit Committee Members of New Zealand Listed Companies. International Journal of Auditing, July, Vol. 22, Iss. 2, pp. 164-184.

${ }^{7}$ Jizi, M. and Nehme, R. (2018). Board Monitoring and Audit Fees: The Moderating Role of CEO/Chair Dual Roles. Managerial Auditing Journal, Vol. 33, Iss. 2, pp. 217-243, https://doi.org/10.1108/MAJ-10-2016-1464.

${ }^{8}$ D'Onza, G. and Sarens, G. (2018). Factors that Enhance the Quality of the Relationships between Internal Auditors and Auditees: Evidence from Italian Companies. International Journal of Auditing, March, Vol. 22, Iss.1, pp. 1-12, https://doi.org/10.1111/ijau.12100.

${ }^{9}$ Onyabe, J.M., Okpanachi, J., Nyor, T., Yahaya, O.A., and Ahmed, M. Supra

${ }^{10}$ Abbott Lawrence J., Parker Susan and Peters Garry F.( 2004) Auditing, A Journal of Practice and Theory 234(1), 69-87, 2004.

${ }^{11}$ AlQadasi, A. and Abidin, S. (2018). The Effectiveness of Internal, Corporate Governance and Audit Quality: The Role of Ownership Concentration - Malaysian Evidence. Corporate Governance: The International Journal of Business in Society, Vol. 18, Iss. 2, pp. 233-253, https://doi.org/10.1108/CG-02-2017-0043.

124 Oluwagbuyi Olusola Luke* Olowolaju Monisola 'Incessant Financial Scandals in the Corporate Organizations in Nigeria: Auditors' Culpability Research Journal of Finance and Accounting’ ISSN 2222-1697 (Paper) ISSN 2222-2847 (Online) Vol.4, No.9, 2013 
increased need to understand the workings of audit committees, as business environments, including regulations change. Audit committees are constituted to strengthen corporate governance, protect firm image and investor confidence. As whistleblowers, they probe projects and programs of management and activities of external auditors, to determine the appropriateness of budgets and accruals. As risk managers, they report on financial valuations, estimates and related financial management to enhance integrated reporting. Audit committees should show a high level of understanding of the company's business, be independent of the company and approach their work with a high level of objectivity and professionalism all the while applying internationally accepted audit standards in their work $^{1}$. The characteristics of members should be evaluated to determine how individual behavioral traits affect how crucial decisions are taken in the committee. So much work has been done in understudying their financial expertise, independence, conformity to local and foreign financial reporting standards, and compensation, in the quest to clarify compliance and effectiveness. Questions have been raised on the committees diversity with claims that including women on the committee yields increased risk avoidance and monitoring depth. However, in measuring the effectiveness of audit committees it is important to track firm earnings and avoid use of biased metrics. The observation from this study points to the fact that the public needs reliable audit reports and it can only be achieved in an atmosphere where the concept of integrity, objectivity, independence and fairness are not threatened, hence the gender of the members of the committee is irrelevant while checking effectiveness. There has also been increased focus on audit committee tenure, frequency of meeting, and size, as it is believed that the longer the members remain on the job the more experience and expertise developed which translates to quality reporting of financial dealings of organizations. The smaller the committees size the more the focus on effective governance. The frequency of meetings held by the committee each financial year is discretionary with no significant impact on the effectiveness of the committee.

\section{REFERENCES}

Abbott Lawrence J., Parker Susan and Peters Garry F.( 2004) Auditing, A Journal of Practice and Theory 234(1), 69-87, 2004

Abernathy, J.L., Kubick, T.R., and Masli, A. (2018).Evidence on the Relation between Managerial Ability and Financial Reporting Timeliness.International Journal of Auditing, February 19. DOI: https://doi.org/10.1111/ijau.12112.

Aldamen, H. and Hollindale, J. (2018).Female Audit Committee Members and their Influence on Audit Fees.Accounting and Finance, March, Vol. 58, Iss. 1, pp. 57-89.

AlQadasi, A. and Abidin, S. (2018). The Effectiveness of Internal, Corporate Governance and Audit Quality: The Role of Ownership Concentration - Malaysian Evidence. Corporate Governance: The International Journal of Business in Society, Vol. 18, Iss. 2, pp. 233-253, https://doi.org/10.1108/CG-02-2017-0043.

Alqatamin, R.M. (2018). Audit Committee Effectiveness and Company Performance: Evidence from Jordan. Accounting and Financial Research, Vol. 7, No. 2, pp. 48-60.

Alvarez, S. and Lopez-Iturriaga, F. (2018). Does Corporate Governance Affect the Valuation of Spanish IPOs? The Role of Ownership Structure and the Board of Directors.Forthcoming, Spanish Journal of Finance and Accounting. Available at SSRN: https://ssrn.com/abstract=3101053.

Amin, A., Lukviarman, N., Suhardjanto, D., and Setiany, E. (2018). Audit Committee Characteristics and AuditEarnings Quality: Empirical Evidence of the Company with Concentrated Ownership. Review of Integrative Business and Economics Research, Vol. 7, Supplementary Iss. 1,pp. 18-33.

Arzubiaga, U., Kotlar, J., De Massis, A., Maseda, A. and Iturralde, T. (2018). Entrepreneurial Orientation and Innovation in Family SMEs: Unveiling the (Actual) Impact of the Board of Directors. Journal of Business Venturing, March.Available Online. https://doi.org/10.1016/j.jbusvent.2018.03.002.

Badolato, P., Donelson, D.C., and Ege, M. (2014). Audit Committee Fiancial Expertise and Earnings Management: The Role of Status. Journal of Accounting and Economics, November-December, Vol. 58, Iss. 2-3, pp. 208230.

Baysinger, B.D. and Butler, H.N. (1985). Corporate Governance and the Board of Directors: Performance Effects of Changes in Board Composition. Journal of Law, Economics, and Organisation, Vol. 1, No.1,pp. 101-124.

Beasley, M.S., Carcello, J.V., Hermanson, D.R., and Neal, T.L. (2010).The Audit Committee Oversight Process. Contemporary Accounting Research, Spring, Vol. 26, Iss. 1, pp. 65-122.

Burgess, Z. and Tharenou, P. (2002). Women Board Directors: Characteristics of the Few. Journal of Business Ethics, April, Vol. 37, Iss. 1, pp. 39-49.

Brazel, J.F. and Schmidt, J.J. (2018). Do Auditors and Audit Committees Lower Fraud Risk by Constraining Inconsistencies between Financial and Non-Financial Measures? Auditing: A Journal of Practice and Theory.In Press. https://doi.org/10.2308/ajpt-52087.

Brennan, N. and Kirwan, C.E. (2015). Audit Committees: Practices, Practitioners and Praxis of Governance.

\footnotetext{
${ }^{1}$ Nigerian Code of Corporate Governance, Principle 20.6
} 
Accounting, Auditing, and Accountability Journal, January, Vol. 28, Iss. 4, pp. 466-493.

Chen, S. and Komal, B. (2018). Audit Committee Financial Expertise and Earnings Quality: A Meta-Analysis. Journal of Business Research, March, Vol. 84, pp. 253-270, https://doi.org/10.1016/j.jbusres.2017.11.048.

Chariri, A. and Januarti, I. (2017). Audit Committee Characteristics and Integrated Reporting: Empirical Study of Companies Listed on the Johannesburg Stock Exchange. European Research Studies Journal, Vol. 20, Iss. 4B, pp. 305-318.

Clatworthy, M. and Lee, E. (2018).Financial Analysts' Role in Valuation and Stewardship.Accounting and Business Research, Vol. 48, No. 1, pp. 1-4.

Cohen, J., Krishnamoorthy, G., and Wright, A. (2017). Enterprise Risk Management and the Financial Reporting Process: The Experiences of Audit Committee Members, CFOs and External Auditors. Contemporary Accounting Research, Summer, Vol. 34, Iss. 2, pp. 1178-1209.

Copnell, T. (2016).Four Key Challenges for Global Audit Committees. UK: Audit Committee Institute, KPMG LLP. https://home.kpmg.com/content/dam/kpmg/pdf/2016/04/Four\%20Key\%20Challenges.pdf. Accessed on May 14, 2018.

Corbetta, G. and Salvato, C.A. (2004). The Board of Directors in Family Firms: One Size Fits All. Family Business Review, June, Vol. 17, Iss. 2, pp. 119-134.

Corten, C., Steijvers, T., and Lybaert, N. (2017). The Effect of Intrafamily Agency Conflicts on Audit Demand in Private Family Firms: The Moderating Role of the Board of Directors. Journal of Family Business Strategy, March, Vol.8, Iss. 1, pp. 13-28.

D’Onza, G. and Sarens, G. (2018). Factors that Enhance the Quality of the Relationships between Internal Auditors and Auditees: Evidence from Italian Companies. International Journal of Auditing, March, Vol. 22, Iss. 1, pp. 1-12, https://doi.org/10.1111/ijau.12100.

Dauda, I.A. (2015). Effectiveness of Audit Committee Practices and the Value of Listed Deposit Money Banks in Nigeria.European Journal of Accounting, Auditing, and Finance Research, June, Vol. 3, No. 6, pp. 80-90.

Defond, M.L., Hann, R.N., and Hu, X. (2005). Does the Market Value Financial Expertise on Audit Committees of Boards of Directors? Journal of Accounting Research, May, Vol. 43, No. 2, pp. 153-193.

DeZoort, F.T., Hermanson, D.R., Archambeault, D.S., and Reed, S.A. (2002). Audit Committee Effectiveness: A Synthesis of the Empirical Audit Committee Literature. Journal of Accounting Literature, Vol. 21, pp. 38-75.

Egwuatu, P. (2017).What CAMA Says on Audit Committee Membership.Vanguard, February 20. Available at: https:/www.vanguardngr.com/2017/02/cama-says-audit-committee-membership/. Accessed on April 30, 2018.

Engel, E., Hayes, R.M., and Wang, X. (2010). Audit Committee Compensation and the Demand for Monitoring of the Financial Reporting Process. Journal of Accounting and Economics, February, Vol. 49, Iss. 1-2, pp. $136-154$

Ghafran, C. and Yasmin, S. (2018). Audit Committee Chair and Financial Reporting Timeliness: A Focus on Financial, Experiential and Monitoring Expertise. International Journal of Auditing, March, Vol. 22, Iss. 1, pp. 13-24.

Guay, W. and Verrecchia, R. (2018).Conservative Disclosure.Financial Reporting.In Press. DOI: https://doi.org/10.2308/jfir-52051.

Gunes, N. and Atilgan, M.S. (2018).Comparison of the Effectiveness of Audit Committees in the UK and Turkish Banks.International Journal of Financial Research, Vol. 7, No. 2, pp. 18-29.

Gunn, J. (2007). XBRL: Opportunities and Challenges in Enhancing Financial Reporting and Assurance Processes. Current Issues in Auditing, Vol. 1, pp. A36-A43.

Hay, D. and Cordery, C. (2018). The Value of Public Sector Audit: Literature and History. Journal of Accounting Literature, June, Vol. 40, pp. 1-15.

Hirshleifer, D. and Teoh, S.H. (2003).Limited Attention, Information Disclosure, and Financial Reporting.Journal of Accounting and Economics, Vol. 36, pp. 337-386.

Ika, S.R. and Ghazali, N.A.M. (2012). Audit Committee Effectiveness and Timeliness of Reporting: Indonesian Evidence. Managerial Auditing Journal, Vol. 27, Iss. 4, pp. 403-424. https://doi.org/10.1108/02686901211217996.

Jizi, M. and Nehme, R. (2018). Board Monitoring and Audit Fees: The Moderating Role of CEO/Chair Dual Roles. Managerial Auditing Journal, Vol. 33, Iss. 2, pp. 217-243, https://doi.org/10.1108/MAJ-10-2016-1464.

Johnston, J. and Nowland, J. (2017). A Research Note: The Informational Benefits of CEO Attendance-byInvitation at Audit Committee Meetings. Journal of Contemporary Accounting and Economics, August, Vol. 13, Iss. 2, pp. 108-118.

Kalelkar, R., Khan, S., and Park, S.J. (2018). Excess Audit Committee Compensation and Audit Pricing.International Journal of Accounting, Auditing and Performance Evaluation, Vol. 14, Iss.2-3, pp. 159182, https://doi.org/10.1504/IJAAPE.2018.091062.

Karamanou, I. and Vafeas, N. (2005). The association between Corporate Boards, Audit Committees, and 
Management Earnings Forecasts: An Empirical Analysis. Journal of Accounting Research, June, Vol. 43, No. 3, pp. 453-486.

Kesner, I.F. (2017). Director's Characteristics and Committee Membership: An Investigation of Type, Occupation, Tenure, and Gender. Academy of Management Journal, November 30, Vol. 31, No. 1, https://doi.org/10.5465/256498.

Klein, A. (2002). Audit Committee, Board of Director Characteristics, and Earnings Management. Journal of Accounting and Economics, August, Vol. 33, Iss. 3, pp. 375-400.

Kim, S. and Klein, A. (2017). Did the 1999 NYSE and NASDAQ Listing Standard Changes on Audit Committee Composition Benefit Investors? The Accounting Review, November, Vol. 92, No. 6, pp. 187-212.

Krishnan, G.V. and Visvanathan, G. (2008). Does the SOX Definition of an Accounting Expert Matter? The Association between Audit Committee Directors' Accounting Expertise and Accounting Conservatism.Contemporary Accounting Research, Fall, Vol. 25, No. 3, pp. 827-857.

Kusnadi, Y., Leong, K.S., Suwardy, T., and Wang, J. (2016). Audit Committees and Financial Reporting Quality in Singapore. Journal of Business Ethics, November, Vol. 139, Iss. 1, pp. 197-214.

Lara, J.M.G., Osma, B.G., and Penalva, F. (2007). Board of Directors' Characteristics and Conditional Accounting Conservatism: Spanish Evidence. European Accounting Review, April 08, Vol. 16, Iss. 4, pp. 727-755.

Lee, G. and Fargher, N.L. (2018). The Role of the Audit Committee in their Oversight of WhistleBlowing.AUDITING: A Journal of Practice and Theory, February, Vol. 37, No. 1, pp. 167-189.

McMullen, D.A. and Raghunandan, K. (1996).Enhancing Audit Committee Effectiveness.Journal of Accountancy, August, Vol. 182, Iss. 2, pp. 79-81.

McMullen, D.A. (1996). Audit Committee Performance: An Investigation of the Consequences Associated with Audit Committees. Accounting, Spring, Vol.15, Iss. 1,pp. 87-103.

Menon, K. and Williams, J.D. (1994).The Use of Audit Committees for Monitoring.Journal of Accounting and Public Policy, Summer, Vol. 13, Iss. 2, pp. 121-139.

Modum, U., Ugwoke, R.O., and Onyeanu, E.O. (2013). Audit Committees and Corporate Performance of Selected Companies Quoted in the Nigerian Stock Exchange: A Perception Analysis. Research Journal of Finance and Accounting, Vol. 4, No. 16, pp. 115-124.

Moses, T. (2016). Audit Committee Number of Meetings and Earnings Management in Quoted Nigerian Banks. International Journal of Advanced Academic Research, Social and Management Sciences, June, Vol. 2, Iss. 6, pp. 14-23.

Narayanaswamy, R., Raghunandan, K., and Rama, D.V. (2015).Satyam Failure and Changes in Indian Audit Committees.Journalof Accounting, Auditing and Finance, October 1, Vol. 30, Iss.4, pp. 529-540.

Onyabe, J.M., Okpanachi, J., Nyor, T., Yahaya, O.A., and Ahmed, M. (2018).Effect of Audit Committee Tenure on Financial Reporting Quality of Listed Deposit Money Banks in Nigeria.European Scientific Journal, February, Vol. 14, No. 4, pp. 257-271.

Ozoanigbo, C.V., Orjinta, I.O., and Ofor, T.N. (2016). Audit Committee Effectiveness and Timeliness of the Financial Reporting In Nigeria. Approaches in International Journal of Research Development, Vol. 10, No. 1, pp. 26-39.

Pandit, G.M., Conway, G.M., and Baker, C.R. (2017). Audit Committee Requirements in Six Major Makets: How Far Have We Come? International Journal of Disclosure and Governance, February, Vol. 14, Iss. 1, pp. 3061.

Partiban, J., Gajula, R., and Cardwell, F. (2017). Is Everything Under Control? Audit Committee Challenges and Priorities. 2017 Global Audit Committee Pulse Survey.KMPG's Audit Committee Institute. Bahrain: KMPG Fakhra. https://home.kpmg.com/content/dam/kpmg/bh/pdf/2017-global-audit-committee-pulse-survey.pdf. Accessed on May 14, 2018.

Pincus, K., Rusbarsky, M., and Wong, J. (1989).Voluntary Formation of Corporate Audit Committees among NASDAQ Firms.Journal of Accounting and Public Policy, Winter, Vol. 8, Iss. 4, pp. 239-265.

Pucheta-Martinez, M.C. and Garcia-Meca, E. (2014).Institutional Investors on Boards and Audit Committees and their Effectson Financial Reporting Quality. Corporate Governance: An International Review, May07. https://doi.org/10.1111/corg.12070.

Pye, A. and Pettigrew, A. (2005). Studying Board Context, Process and Dynamics: Some Challenges for the Future. British Journal of Management, March, Vol. 16, Iss. S1, pp. 527-538. https://doi.org/10.1111/j.14678551.2005.00445.x.

Rani, A. (2018). Audit Committee Effectiveness: Relationship between Audit Committee Characteristics and Audit Fees and Non-Audit Service Fees. Journal of Commerce and Accounting Research, Vol. 7, Iss.3, pp.3544.

Rezaee, Z., Olibe, K.O., and Minmier, G. (2003).Improving Corporate Governance: The Role of Audit Committee Disclosures.Managerial Auditing Journal, Vol. 18, Iss. 6/7, pp. 530-537, https://doi.org/10.1108/02686900310482669. 
Robert Wearing, Cases in Corporate Governance, Sage Publications (London, Published by SAGE Publications Ltd., 2005)

Schrader, C.L. (2017). The Impact of Audit Committee Tenure and Compensation on Audit Fees.Ph.D Thesis, Morgan State University, Baltimore, USA. Available at: https://mdsoar.org/bitstream/handle/11603/10551/Schrader_morgan_0755D_10719.pdf?sequence=1. Accessed on June 21, 2018.

Sharma, V., Naiker, V., and Lee, B. (2009). Determinants of Audit Committee Meeting Frequency: Evidence from a Voluntary Governance System. Accounting Horizons, September, Vol. 23, No. 3, pp. 245-263.

Song, J. and Windram, B. (2004).Benchmarking Audit Committee Effectiveness in Financial Reporting.International Journal of Auditing, November, Vol. 8, Iss. 3, pp. 195-205.

Srinivasan, S. (2005). Consequences of Financial Reporting Failure for Outside Directors: Evidence from Accounting Restatements and Audit Committee Members. Journal of Accounting Research, May, Vol. 43, Iss. 2, pp. 291-334.

Turley, S. and Zaman, M. (2004).The Corporate Governance Effects of Audit Committees.Journal of Management and Governance, September, Vol. 8, Iss. 3, pp. 305-332.

Turley, S. and Zaman, M. (2007). Audit Committee Effectiveness: Informal Processes and Behavioural Effects. Accounting, Auditing and Accountability Journal, Vol. 20, No. 5, pp. 765-788.

Van der Walt, N. and Ingley, C. (2000).Evaluating Board Effectiveness: The Changing Context of Strategic Governance.Journal of Change Management, Vol. 1, Iss. 4, pp. 313-331. https://doi.org/10.1080/738552741.

VanPeteghem, M., Bruynseels, L., and Gaeremynck, A. (2018). Beyond Diversity: A Tale of Faultlines and Frictions in the Board of Directors. The Accounting Review, March, Vol. 93, No. 2, pp. 339-367.

Velte, P. (2018). Does Geeder Diversity in the Audit Committee Influence Key Audit Matters Readability in the Audit Report? UK Evidence.Corporate Social Responsibility and Environmental Management, March 23, https://doi.org/10.1002/csr.1491.

Verschoor, C.C. (2008). Audit Committee Essentials. USA: John Wiley \& Sons.

Wu, J., Habib, A., Weil, S., and Wild, S. (2018). Exploring the Identity of Audit Committee Members of New Zealand Listed Companies. International Journal of Auditing, July, Vol. 22, Iss. 2, pp. 164-184.

Yang, J.S. and Krishnan, J. (2005). Audit Committees and Quarterly Earnings Management. International Journal of Auditing, December 16. https://doi.org/10.1111/j.1099-1123.2005.00278.x.

Yermack, D. (1996). Higher Market Valuation of Companies with a Small Board of Directors.Journal of Financial Economics, February, Vol. 40, Iss. 2, pp. 185-211.

Young, A. (2018). Do Analysts affect Bad News Timeliness? Accounting and Business Research, Vol. 48, Iss. 2 , pp. 171-189.

Zalata, A.M., Tauringana, V., and Tingbani, I. (2018). Audit Committee Financial Expertise, Gender, and Earnings Management: Does Gender of the Financial Expert Matter? International Review of Financial Analysis, January, Vol. 55, pp. 170-183, https://doi.org/10.1016/j.irfa.2017.11.002. 